\title{
Improving Students' Vocabulary Mastery by Using Total Physical Response
}

\author{
Fahrurrozi $^{1}$ \\ ${ }^{1}$ Jakarta State University, Indonesia \\ Correspondence: Fahrurrozi, Jakarta State University, Indonesia. Tel: 62-021-525-4912. E-mail: \\ ozipasca@gmail.com
}

Received: January 4, 2017 Accepted: February 8, 2017 Online Published: February 11, 2017

doi: 10.5539/elt.v10n3p118 URL: http://doi.org/10.5539/elt.v10n3p118

\begin{abstract}
This study aims to describe how Total Physical Response improves students' vocabulary learning outcomes at the third-grade elementary school Guntur 03 South Jakarta, Indonesia. This research was conducted in the first semester of the academic year 2015 - 2016 with the number of students as many as 40 students. The method used in this research is a Classroom Action Research using the cycle model of Kemmis and Taggart. Class Action Research is conducted through the plan, class action or implementation, observation, and reflection stages. The data collection was done by using a non-test, test instruments and monitoring instruments in the form of action, and field notes. Validity and reliability of the instrument were reached through expert judgment. The results obtained from this study was the improvement in vocabulary learning outcomes of students by applying the Total Physical Response (TPR) method. Percentage of learning outcomes in the first cycle reached $74.13 \%$ and $83.38 \%$ in the second cycle. The percentage shows improvement of learning effectiveness by applying the Total Physical Response method. The first cycle resulted in an improvement of $64.29 \%$ and the second cycle resulted in an increase of $87.14 \%$. Thus, learning process by using Total Physical Response (TPR) can improve students' vocabulary learning outcomes. The implication of this study is that teaching vocabulary using the Total Physical Response is more effective.
\end{abstract}

Keywords: vocabulary mastery, total physical response

\section{Introduction}

Subjects in English is a subject that must be mastered by the students. This is in line with the vision of national education goals set forth in the Strategic Plan of the Ministry of National Education Year 2005-2009 which states that by the year of 2025 the national education is expected to produce "Indonesian people who are intelligent and competitive". Meanings contained in the "intelligent and competitive" superior personality and devotion to striving for excellence, passionate perseverance, self-sufficient, persistence, innovative and become agents of change, productive, quality conscious, globally oriented, and lifelong learners. However, in reality, English as one of the subjects that develop competitive still considered as a difficult one for students.

The negative attitude of students on English would have a negative impact on the learning process in the classroom. The poor learning process in the classroom will eventually result in lower vocabulary learning outcomes of students. Therefore, the process of learning English needs special attention.

The poor process of learning English in elementary schools can be caused by various factors; student, teachers, teaching and learning, as well as facilities and infrastructure. The roles of a teacher in the implementation of teaching and learning in primary school are deemed extremely important. Why is that important? Because the teacher is the key to a good education. Teachers should act as educators, counselors, and innovator. Given the important roles of the teacher in the learning, the teachers' competence must be considered and improved so that teachers as educators can implement the learning process effectively included in the process of learning English.

The success of the learning process is included in the teaching of English strongly influenced by various aspects such mastery of the material and the way teachers deliver material. There is the possibility of low competence of students in mastering the teaching materials are delivered by teachers due to lack of competence of teachers in selecting and using teaching methods. There are some teachers who have chosen teaching methods, appropriate teaching materials but have not been able to apply the learning methods well. In addition, there are still many 
teachers who use conventional teaching methods that do not engage students actively in the learning process.

Mastery of vocabulary as one components of language is very important. As stated by Qian (2002, p. 515) that breadth of knowledge refers to "the number words the meaning of which one has at least some superficial knowledge". It means that learners should master many words number so that they can learn easily. They also have to master vocabulary related to their level of education. Nunan (1998: 117) pointed out that "one of the most was the easiest aspects of language to learn and that it hardly required formal attention". Pity (2008: 43) argues at least English vocabulary need to be studied by elementary school students was estimated at approximately 500 words.

Based on the precondition of the field research found that the average value of English lesson at the third-grade students of elementary school Guntur 03 South Jakarta, Indonesia is still below the minimum standard of mastery learning as determined by the school is $80 \%$. The difficulty of the students especially in the mastery of vocabulary is generally caused by the material presented in form of teacher center and classical. Lessons are conducted by teachers to make students are not involved actively in learning. Such circumstances lead English language learning class which requires the mastery of vocabulary becomes ineffective. It can occur because the selected methods by teachers are not suitable to the materials.

Basically, learning is a process of changing in behavior caused by the experience. Changes as a result of the learning process can be shown in the form of changes in knowledge, understanding, attitudes and behaviors, skills, habits, and any change other aspects that exist in individual learning. Learning by Slameto (2003: 2) is a process of a person attempts to obtain a new change in behavior as a whole, as a result of his own experience in interaction with the environment.

According to Sudjana (2001: 22), the result of learning abilities of the students is after receiving their learning experience. Those definitions can be understood that after students receive a learning experience, then change it into behavior, so students will have their new abilities.

In learning languages, including learning English language, vocabulary is one of the important things to master besides other components likes: grammar and pronunciation. Because vocabulary is a key to language skills. As Richards and Renandya (2002: 255) state vocabulary is also an important core of language proficiency and it provides much of a basis for how well learners speak, listen, read, and write. Vocabulary is a central to the proficiency and gives an overview of how well students can speak, hear, read, and write.

There are some principles or guidelines that can be used as consideration by teachers in teaching vocabulary. Wallace (1982: 27) describes the principles or guidelines in teaching vocabulary, which include: aims, quantity, need, frequent exposure and repetition, meaningful presentation, presentation in situation and context. In the interview vocabulary students are given the opportunity to do a question and answer to the teacher or the other students on vocabulary. According to Nation (2001, pp. 107-108) at the second - hand cloze, vocabulary teaching procedure includes three steps, namely the students read the text that contains the uptake vocabulary, students deliberately learning vocabulary and students are given cloze passages from the summary of what they actually read.

Selection of appropriate learning methods can be done by considering various things and aspects. Surakhmad in Djamarah (2006: 78) reveals that in choosing learning methods, it needs to consider the students, learning objectives, learning situation, facilities, and the ability of teachers themselves to manage learning methods used. Thus the selection of instructional methods carried out by the teacher must be observed both from the competence of teachers, students, and the learning environment.

One of the methods that can be applied by teachers in an effort to improve the competence of students in learning English, especially in the mastery of vocabulary is by applying the method of Total Physical Response (TPR). TPR is one method of learning in teaching English as a foreign language developed by James Asher, a psychology professor at San Jose State University. Furthermore, Richards and Rogers (2011: 73) revealed the Total Physical Response is a language teaching method built around coordination of speech and action, it attempts to teach language through physical activity. Total Physical Response is a language teaching method that is based on coordination between speech and action, the method for teaching languages using motor physical activity.

It is a suitable method to teach English to children in particular mastery of vocabulary because in implementation of learning, it more emphasizes on activities directly related to physical activity and movement. It means more frequent or more intense stimulation of memory a person is given the stronger the memory associations connected and easier to remember. Memorizing is done verbally by the motion activity or motor activity. Firstly, 
in such activities, children listen and then understand messages, decide whether they are right or wrong, and finally act accordingly (Pinter, 2006)

TPR provides a greater emphasis on forms of command instruction that is easy to use by the teacher and understood by students because it is done with the demonstration. There are some assumptions about language learning must be considered when teaching English as a foreign language to children, one of the assumptions is the meaning to be given to concrete objects or by giving a presented experience. By the application of TPR method in learning English vocabulary, the students are expected to increase their vocabulary learning outcome. In addition, TPR also stressed the effectiveness of learning so that the learning process is carried out by teachers and students will achieve the learning objectives that have been defined previously.

Another opinion regarding TPR stated by Larsen and Freeman (2000: 107), which revealed the TPR is an approach to understanding a foreign language with instructions or orders. Larsen and Freeman called the TPR as an approach to understanding because in practice the students are given instructions or commands that can enhance students' understanding of the material presented. Based on the descriptions, the aim of the research is to know how Total Physical Response improves students' vocabulary mastery. Formulation of the research is as follow: Can Total Physical Response method improve students' vocabulary mastery? In other words, the theoretical hypothesis of the research is Total Physical Response can improve students' vocabulary mastery.

\section{Method}

The Research was conducted at the third grade of elementary students Guntur 03 South Jakarta, Indonesia. The number of students was 40 students. It was done for 4 months, from July to October 2015. The method used was a Classroom Action Research or often known as "Penelitian Tindakan Kelas" in the Indonesian language. The process was a cycle model, round or spiral. Cycle referred to a round activity that consists of several activities, namely: plan, action, observation, and reflection (Wijaya, 2009: 21). The design of intervention actions or design cycle research was using the Kemmis and Taggart model. Working procedures of action research by model Kemmis and Taggart, essentially a cycle that includes the steps of (a) plan, (b) acts, (c) observation, and (d) reflection, followed by re-planning, re-acting, re-observing, and re-reflecting for the next cycle.

The procedures done were firstly, observing before acting to know the class condition before the research conducted. Secondly the researcher as a plan leader has to decide the time, lesson plan, media controlled action instrument, then to evaluate vocabulary in learning English in the class. Specific planning was arranged per cycle. The plan was done by researcher and his collaborators (head master, English teachers in the school). Third, acting process in the classroom teaching of vocabulary by using TPR. It was conducted into two cycles with allocation time is the same with regular time at the school. Next step is observing process was done to recognize and evaluate the development of acting result. Whether the action done related to the planning or not. And it was also to see the increase of students' vocabulary mastery from the pretest to the post-test (post-test 1 and post-test 2). In observing phase, the researcher observed all the activities done by the subjects of the research (40 students). It was noted by having field notes in order all the data in the process of observing can be documented completely. The notes also contain by reflection. Besides, the observer also recorded the activity by using the camera in order the data collected can be achieved perfectly. The last stage is reflecting. This stage is very important, because it is to evaluate critically the changes process happened in the classroom. The changes were related to the students' activities, class condition, and teacher's activities. This stage was also done to know and analyze the achievement and factors which cause the failure of the given action. And the last function of the reflecting is to compare students' vocabulary achievement before and after action. If the result showed has not fulfilled the criteria of the success $(80 \%)$, the cycle should be continued to the next cycles. But if the result has passed the standard criteria mentioned, the research should be stopped.

There are two types of data sources in research action were given, namely (1) the data monitoring actions, and (2) research data. Data monitoring actions in the research is English learning activities conducted at the third-grade elementary school students' Guntur 03 south Jakarta, Indonesia. The research data were the result of learning vocabulary of the students from pretest, post-test 1 , and post-test 2 .

\section{Results}

\subsection{The Results of Post Observational Note and Post Test}

\subsubsection{Cycle 1}

Based on the results of observation, there are some proofs found in the implementation of the action either at the first meeting and the second meeting in the cycle I. The findings obtained the teacher does not explain the learning objectives at the beginning of the learning, the teacher less provided an opportunity to speak 
individually to students so that students do not dare to speak in English and the students were less active in asking though students are not interested in learning English. Other findings obtained is the use of media, especially text of the song that is less attractive to students because it only form of lyrics. Then, perception was done that singing is more effective than simply watching the pictures alone. Besides, there are some students who do not understand how to use the answer model of true or false.

The most important thing in the implementation of the action in the first cycle is the application of TPR should be maximized. This can be proved by activity of students in asking questions and talking that still needs to be improved. The other thing is the selected media in order to attract students' activity. In addition, there are some students who do not understand fully exercises in the form of true - false.

Table 1. The result of post observational note of cycle 1

\begin{tabular}{|c|c|c|}
\hline No. & Observed Aspects & The Result of Data Observation \\
\hline 1. & $\begin{array}{l}\text { Teacher demonstrated the lesson } \\
\text { based on the context }\end{array}$ & $\begin{array}{l}\text { The teacher already used body expression and doing translation } \\
\text { of the word with the demonstration, and already expressed orally } \\
\text { in learning }\end{array}$ \\
\hline 2. & Teacher delivered the aim of lesson & $\begin{array}{l}\text { The teacher does not deliver the learning objectives at the } \\
\text { beginning of learning but the teacher has already linked material } \\
\text { learned to the material that will be taught. }\end{array}$ \\
\hline 3. & Teacher motivated students & $\begin{array}{l}\text { The teacher seemed flexible and friendly to students and he can } \\
\text { give encouragement to their students and has been able to } \\
\text { increase the confidence of students }\end{array}$ \\
\hline 4. & $\begin{array}{l}\text { The teacher gave his attention to } \\
\text { students' speaking when they } \\
\text { produced some vocabularies. }\end{array}$ & $\begin{array}{l}\text { The teacher does not give students the opportunity to speak and } \\
\text { write }\end{array}$ \\
\hline 5. & $\begin{array}{l}\text { Teacher helped students imitating and } \\
\text { practicing vocabulary }\end{array}$ & $\begin{array}{l}\text { The teacher did not give students enough opportunity to repeat } \\
\text { the words from teachers and did not repeat the correct } \\
\text { pronunciation of students' vocabulary. }\end{array}$ \\
\hline 6. & Teacher maximized students' senses & $\begin{array}{l}\text { The teacher already stimulated the senses of sight and the } \\
\text { students were already maximizing the senses of students' } \\
\text { hearing. }\end{array}$ \\
\hline 7. & $\begin{array}{l}\text { Teacher revised students' mistakes } \\
\text { without lowering the students' } \\
\text { confidence }\end{array}$ & $\begin{array}{l}\text { The teacher was able to foster self-confidence of students, aware } \\
\text { of its advantages and disadvantages, and revise students' } \\
\text { mistakes politely. }\end{array}$ \\
\hline 8. & $\begin{array}{l}\text { Students performed the demonstration } \\
\text { ordered }\end{array}$ & $\begin{array}{l}\text { Students were able to do and understand the teachers' rules and } \\
\text { be able to follow the lesson as instructed by the teacher. }\end{array}$ \\
\hline 9. & $\begin{array}{l}\text { Students were enthusiastic about } \\
\text { learning }\end{array}$ & $\begin{array}{l}\text { Students have started a passionate and interested in learning but } \\
\text { have not actively to ask some questions. }\end{array}$ \\
\hline 10. & $\begin{array}{l}\text { Students received a definition of a } \\
\text { word without teacher's translation }\end{array}$ & $\begin{array}{l}\text { Students can define a word without direct translation from the } \\
\text { teacher, but it was from teachers' movements. }\end{array}$ \\
\hline 11. & Students dared to speak in English & $\begin{array}{l}\text { Students did not dare to speak in English but only to answer } \\
\text { simple questions from the teacher }\end{array}$ \\
\hline 12. & $\begin{array}{l}\text { Students maximized his senses in the } \\
\text { learning }\end{array}$ & $\begin{array}{l}\text { Students were already maximizing the senses of sight and } \\
\text { hearing, but have not been helped by using the media. }\end{array}$ \\
\hline 13. & $\begin{array}{l}\text { Students were not strained when } \\
\text { learning takes place }\end{array}$ & Students felt relaxed and were not anxious in learning. \\
\hline
\end{tabular}


Table 2. The result Post-Test I on Cycle I

\begin{tabular}{|c|c|c|c|}
\hline No. & scores & Number of students & Percentage (\%) \\
\hline 1. & $25-35$ & 4 & 10 \\
\hline 2. & $36-46$ & 0 & 0 \\
\hline 3. & $47-57$ & 4 & 10 \\
\hline 4. & $58-68$ & 7 & 17,5 \\
\hline 5. & $69-79$ & 4 & 10 \\
\hline 6. & $80-90$ & 14 & 35 \\
\hline 7. & $91-100$ & 7 & 17,5 \\
\hline \multicolumn{2}{|c|}{ Total } & 40 & 100 \\
\hline \multicolumn{2}{|c|}{ Class means score } & & 74,13 \\
\hline
\end{tabular}

Based on the tables and diagrams Data Analysis Results Test Cycle I, there are four students who have grades $25-35$ or $10 \%$ of total students. Meanwhile, there are no students who have grades 36-46 while students who have grades $45-57$ amounted to 4 students, or about $10 \%$ of the total number of students. Students who have the grades 58-68 amounted to 7 students, or $17.5 \%$ of the number of students, students who have grades 69-79 students amounted to 4 students, or $10 \%$ of the existing number of students, students who have grades $80-90$ amounted to 14 students or about 35 percent, while students who have grades 91-100 amounted to 7 students, or $17.5 \%$ of the total students. Under these conditions, the average grade obtained is 74.13 or the percentages amounted to $74.13 \%$.

Based on the analysis of vocabulary learning outcomes of students in the first cycle can be illustrated by the following bar chart.

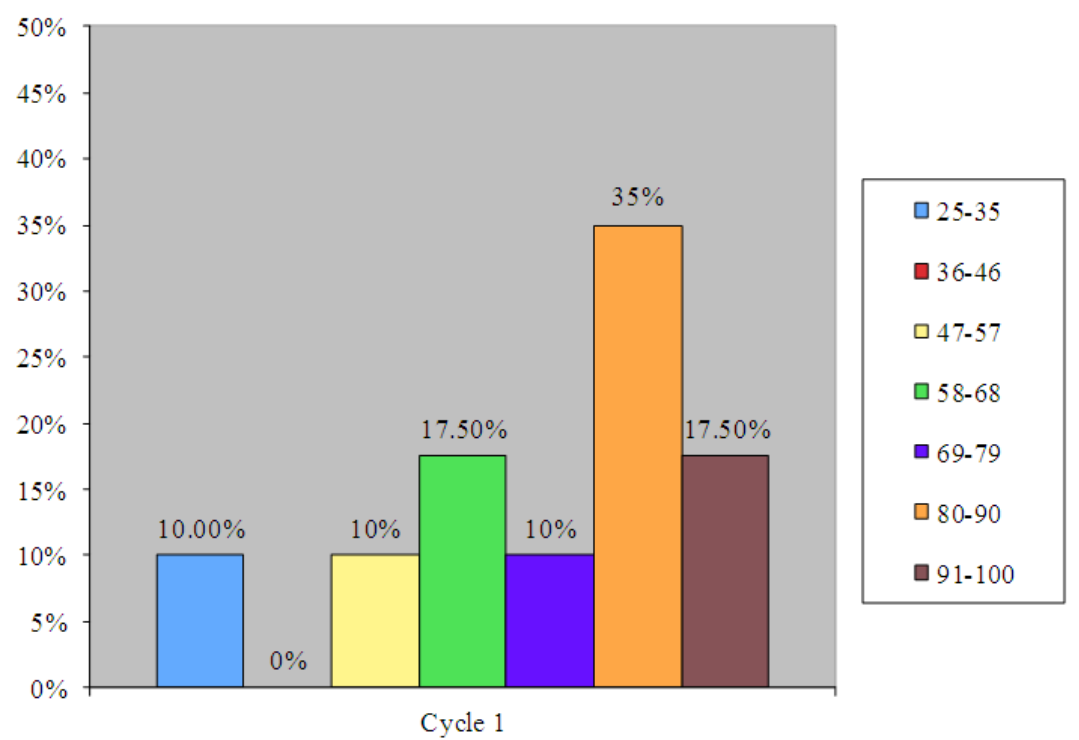

Figure 1. Diagram of students' vocabulary learning outcomes of the first cycle

Based on the diagram contained the highest percentage on the value of $80-90$ is $35 \%$ of the total number of students, while the lowest percentages are in grades 36-46 is $0 \%$.

\subsection{The results of Observational Note and Post test}

\subsubsection{Cycle II}

Based on the results of observation, there are some data found in the act of both the first meeting and the second meeting in the second cycle. The findings, among others, students were beginning to dare to speak in English 
even though still in the simple way, besides the second cycle teachers are also gradually began to deliver the learning objectives at the beginning of each learning process.

In addition, based on field notes and instruments monitoring the actions made by the observer, the teacher has provided the opportunity for students to speak in English. Observer and researcher also see almost all of the students have been able to demonstrate sentence instruction properly.

The most important thing in the implementation of the action on the second cycle is the application of TPR methods in the learning process is getting better. This was an evidence in the results of the test in this cycle has been above the average of the pretest or in other words the research had been completed. Based on the data acquisition, the administration of the action ends up with the second cycle.

Table 1. The revising plan on the second cycle

\begin{tabular}{lll}
\hline No. & Findings of Cycle I & Revising plan on the Second Cycle \\
\hline 1. & $\begin{array}{l}\text { Teacher do not deliver the learning } \\
\text { objectives at the beginning of learning }\end{array}$ & $\begin{array}{l}\text { Teachers deliver the learning objectives at the beginning of } \\
\text { learning after linking the material already learned to the } \\
\text { material that will be taught }\end{array}$ \\
\hline 2. & $\begin{array}{l}\text { Teachers are not stressing students' } \\
\text { speaking ability }\end{array}$ & $\begin{array}{l}\text { Teacher give students the opportunity to speak and write } \\
\text { through game }\end{array}$ \\
\hline 3. & $\begin{array}{l}\text { Teachers is less to help students imitate } \\
\text { and practice their vocabulary }\end{array}$ & $\begin{array}{l}\text { Teacher give students the opportunity to repeat the words of } \\
\text { teachers and students to repeat the pronunciation of vocabulary }\end{array}$ \\
\hline $4 . \quad \begin{array}{l}\text { Students are not actively to ask } \\
\text { questions in learning }\end{array}$ & Teacher provided time for students to ask \\
\hline 5. & $\begin{array}{l}\text { Students do not dare to speak in } \\
\text { English }\end{array}$ & $\begin{array}{l}\text { Teacher designed games that stimulate students to speak in } \\
\text { English }\end{array}$ \\
\hline $6 . \quad \begin{array}{l}\text { Students are not maximizing their } \\
\text { senses in the learning }\end{array}$ & Teacher designed games that can maximize students' senses \\
\hline 7. & The use of uninterested media & Teacher designed games that can maximize students' senses \\
\hline
\end{tabular}

Meanwhile, the vocabulary learning outcomes of students in the second cycle can be illustrated in the diagram below.

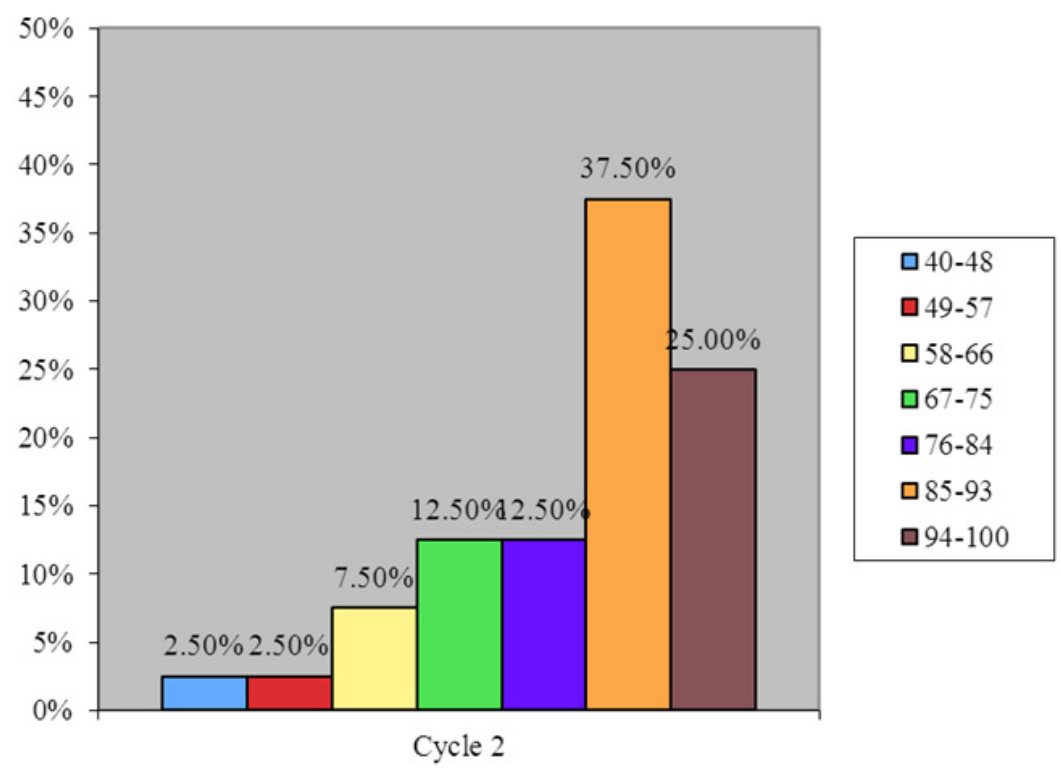

Figure 2. Diagram of students' vocabulary learning outcomes of the second cycle 
Based on the diagram contained the highest percentage on the value of $85-93$, namely $37.50 \%$ of the total number of students, while the lowest percentages are in grades $40-48$ and $49-57$ is $2.50 \%$.

Based on the analysis of vocabulary learning outcomes of students in cycle I and II, it can be described average vocabulary learning outcomes in cycles I and II through the following bar chart.

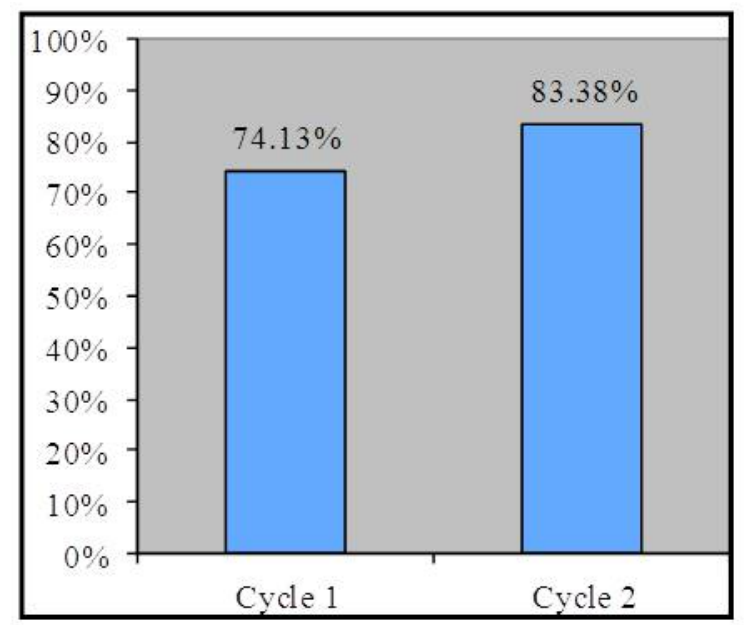

Figure 3. Average results of students learning vocabulary

Based on an average diagram vocabulary learning outcomes of students in the above, it can be concluded that vocabulary learning outcomes in the first cycle reaches $74.13 \%$ to $83.38 \%$, or in other words an increase of $9.25 \%$.

The results of monitoring action learning by applying TPR in the first cycle can be depicted on the bar chart below.

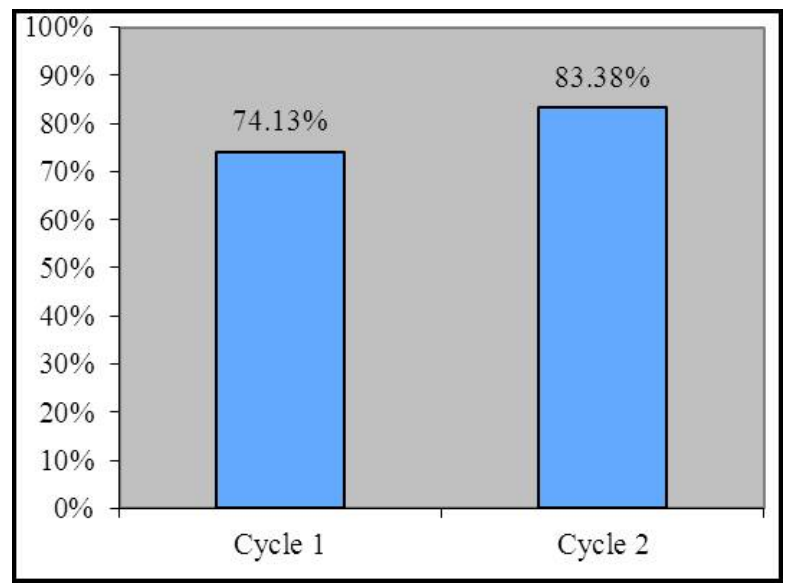

Figure 4. Diagram monitoring action learning through TPR in the first cycle

Based on monitoring diagram action learning through TPR in the first cycle, there was an increase in the first meeting to meeting II. At the first meeting reached $57.14 \%$ while in attendance II reached $71.43 \%$, or in other words an increase of $14.29 \%$.

The results of monitoring action learning by applying TPR in the second cycle can be depicted on the bar chart below. 


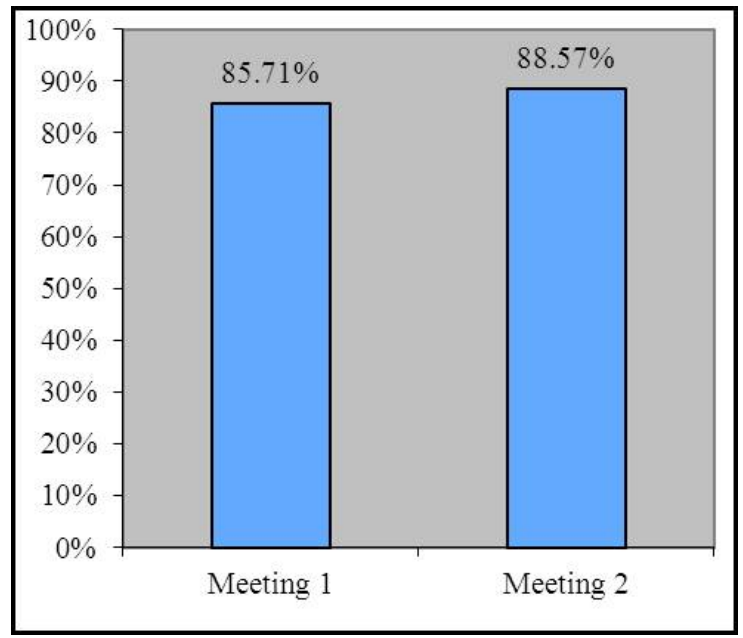

Figure 5. Diagram monitoring action learning through TPR method on the second cycle

Based on monitoring diagram action learning through TPR method in the second cycle there was an increase in the first meeting to meeting II. At the first meeting reached $85.71 \%$ while in attendance II reached $88.57 \%$, or in other words an increase of $2.86 \%$.

Based on the monitoring of action learning by applying the method of TPR for two cycles, it can be concluded that the learning is done by applying the method of TPR has increased very well. It can also be seen in the diagram the average results of the monitoring instruments of action learning by applying the method of TPR for two cycles that can be described in the following bar chart.

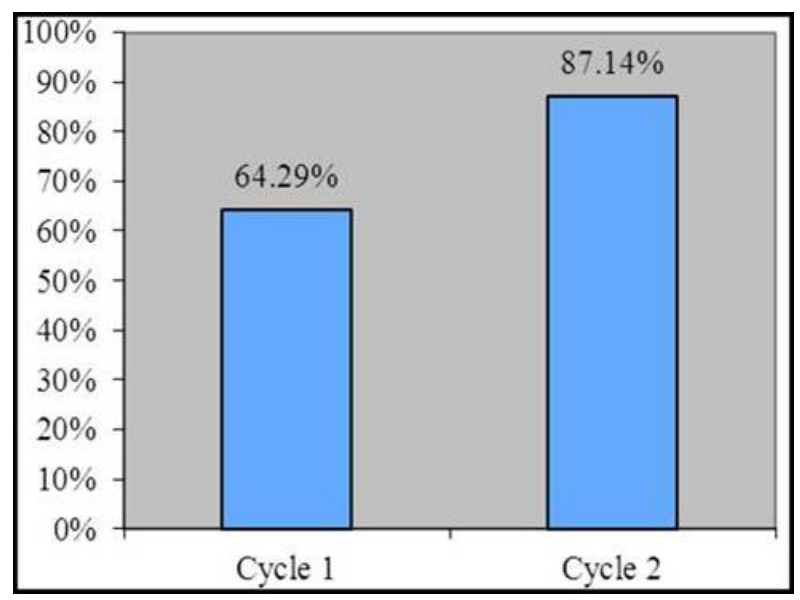

Figure 6. Diagram of the average observer action learning through TPR

Based on the diagram average yielded instrument monitors of the act of learning by applying TPR during two cycles of the above, it can be concluded that learning by applying TPR was very good. Students get the translation of words through movements by teachers, friends, or by themselves, so they can understand words or sentences in English.

\section{Discussion}

Based on the analysis results of cycle I and II, it can be seen an improvement of all captured data. The results of the data analysis of student vocabulary learning outcomes can be seen in the following table: 
Table 4. Improvement of vocabulary learning outcomes during the two cycles

\begin{tabular}{lll}
\hline No. & Data of every cycle & Percentages of learning outcomes \\
\hline 1. & cycles I & $74,13 \%$ \\
2. & cycle II & $83,38 \%$ \\
The improvement of vocabulary learning outcomes & $9,25 \%$ \\
\hline
\end{tabular}

The results of the monitoring actions / non-test instruments can be seen in the following table:

Table 5. The improvement results of controlled action during the two cycle

\begin{tabular}{lll}
\hline No. & Data in every cycle & Percentages of controlled action \\
\hline 1. & Cycle I & $64,29 \%$ \\
2. & cycles II & $87,14 \%$ \\
The improvement of controlled action & $22,85 \%$ \\
\hline
\end{tabular}

Based on the table, the increase from the learning outcomes and monitors the actions, then there is an improvement on students' vocabulary mastery learning outcomes through the TPR method. Cycle I-II showed that vocabulary learning outcome reached $9.25 \%$ and $22.85 \%$ increased in monitoring action. The improvement of students vocabulary learning outcomes with TPR method apparently found an increase from the first cycle to the second cycle. This increase shows that the identification and analysis of researcher along with collaborators on the findings of the problems that occur in each cycle have been found and showed optimal results.

\section{Conclusion and Recommendation}

TPR implementation in the classroom to improve learning out comes of students' vocabulary by making the vocabulary of students physically, activate students through role-modeling that can be translated to students as the meaning of a word in the English language so that the students' understanding of vocabulary increases. Besides the application of TPR in the classroom, it can also make English language learning of students who previously daunting for even more fun so that students can follow the learning process to the optimum result.

\section{Acknowledgment}

Firstly, the researcher wants to give his great thanks to the Head Master of the school who has given his permission to the researcher to conduct the research. And second salutation goes to collaborators who have given and spent their time to help him in collecting the data. And last thanks to students' of the class action research who have participated in the process of learning during the research.

\section{References}

Diane, L., \& Freeman. (2000). Technique and Principles in Language Teaching. New York: Oxford University Press.

Djamarah, S. B. (2006). Strategi Belajar Mengajar. Jakarta: Rineka Cipta.

Vacca, Jo., Anne, L., Richard, T. V., \& Marry, K. G. (1987). Reading and learning to read. Boston:Little Brown \& Company,

Kusumah, Wijaya dan Dedi Dwitagama. (2009). Mengenal Penelitian Tindakan Kelas. Jakarta: Indeks.

Larsen, D., \& Freeman. (2000). Technique and Principles in Language Teaching (New York: Oxford University Press.

Nana, S. (2001). Penilaian Hasil Proses Belajar Mengajar. Bandung: Remaja Rosdakarya.

Nation, I. S. P. (2001). Learning Vocabulary in Another Language. Cambridge: Cambridge Univesity Press. https://doi.org/10.1017/CBO9781139524759

Nunan, D. (1998). Language Teaching Methodology. New York: Prentice Hall.

Pinter, A. (2006). Teaching Young Learners. China: Oxford University Press. https://doi.org/10.1002/t1.235

Qian, D. D. (2002). Investigating the Relationship between the Vocabulary Knowledge and Academic Reading 
Performance: An assessment perspective. Language learning, 52, 513-536. https://doi.org/10.1111/1467-9922.00193

Richards \& Renandya. (2002). Methodology in Language Teaching. London: Cambridge University Press. https://doi.org/10.1017/CBO9780511667190.041

Richards, J., \& Rogers, (2001). Approaches and Methods in Language Teaching. London: Cambridge University Press. https://doi.org/10.1017/CBO9780511667305

Setiyadi, Bambang. (2006). Teaching English As A Foreign English. Yogyakarta: Griya Ilmu.

Slameto. (2003). Belajar dan Faktor-Faktor yang Mempengaruhinya. Jakarta: Rineka Cipta.

Suyanto, E. K. (2008). English For Young Learners. Jakarta: Bumi Aksara.

Wallace, J. M. (1982). Teaching Vocabulary. London: English Languange Book Society.

\section{Copyrights}

Copyright for this article is retained by the author(s), with first publication rights granted to the journal.

This is an open-access article distributed under the terms and conditions of the Creative Commons Attribution license (http://creativecommons.org/licenses/by/4.0/). 